\title{
Bacteriocin Producing Probiotic Lactic acid Bacteria
}

\section{Nishant Toomula ${ }^{1 *}$, Sathish Kumar $\mathrm{D}^{2}$, Arun Kumar $\mathbf{R}^{3}$, Hima Bindu $\mathrm{K}^{4}$ and Raviteja $\mathrm{Y}^{5}$}

${ }^{1}$ Department of Biotechnology, GITAM Institute of Technology, GITAM University, Visakhapatnam, India

${ }^{2}$ Department of Biotechnology, University of Hyderabad, Hyderabad, India

${ }^{3}$ Department of Biochemistry, GITAM University, Visakhapatnam, India

${ }^{4}$ Department of Microbiology, A.Q.J.P.G College, Andhra University, Visakhapatnam, India

${ }^{5}$ Department of Biochemistry, Dr.L. Bullayya P.G College, Andhra University, Visakhapatnam, India

\begin{abstract}
Human intestinal tract is filled with an enormous number of helpful bacteria called probiotic bacteria. Human bodies are actually designed to have symbiotic relationships with these probiotic bacteria. They help in digestion of food, killing harmful microorganisms and keep the body functioning properly in a number of ways. Lactic acid bacteria including Lactobacillus leuconostoc, lactococcus, pediococcus and Bifidobacterium are found throughout the gastrointestinal tract. The beneficial effects of Lactic acid bacteria as probiotic and production of bacteriocin is discussed in this article.
\end{abstract}

Keywords: LAB (Lactic acid Bacteria); Bacteriocins; Nisin; Food preservation

\section{Introduction}

Lactic acid bacteria (LAB) and bifidobacteria are the most common types of microbes used as probiotics [1]. Probiotics are commonly consumed as part of fermented foods with specially added active live cultures; such as in yogurt [2], soy yogurt, or as dietary supplements.

Lactic acid bacteria are Gram-positive bacteria, usually nonmotile, non-spore-forming rods and cocci which are able to grow both in the presence and absence of oxygen. They have a long history of application in fermented foods because of their beneficial influence on nutritional, organoleptic, and shelf-life characteristics [3]. Lactic acid bacteria cause rapid acidification of the raw material through the production of organic acids, mainly lactic acid [4]. In addition, their production of acetic acid, ethanol [5], aroma compounds, bacteriocins, exopolysaccharides, and several enzymes is of importance (Figure 1). Whereas a food fermentation process with LAB is traditionally based on spontaneous fermentation or backslopping, industrial food fermentation is nowadays performed by the deliberate addition of LAB as starter cultures to the food matrix. This has been a breakthrough in the processing of fermented foods [6], resulting in a high degree of control over the fermentation process and standardization of the end products.

The genus Lactobacillus currently consists of over 125 species and encompasses a wide variety of organisms. The species which have been therapeutically used are:

- L. sporogenes

- L. acidophilus

- L. plantarum

- L. casei

- L. brevis

- L. delbruckii

- L. lactis

Lactic acid bacteria produce antibacterial compounds that are known as bacteriocins [7]. Bacteriocins act by punching holes through the membrane that surrounds the bacteria. Thus, bacteriocins activity is usually lethal to the bacteria. Examples of bacteriocins are nisin and leucocin. Nisin inhibits the growth of most gram-positive bacteria, particularly spore-formers (e.g., Clostridium botulinum). This bacteriocin has been approved for use as a food preservative in the United States since 1989. Lactic acid bacteria are also of economic importance in the preservation of agricultural crops and in the biodegradation $[8,9]$. A popular method of crop preservation utilizes what is termed silage. Silage is essentially the exposure of crops (e.g., grasses, corn, and alfalfa) to lactic acid bacteria [10]. The resulting fermentation activity lowers the $\mathrm{pH}$ on the surface of the crop, preventing colonization of the crop by unwanted microorganisms.

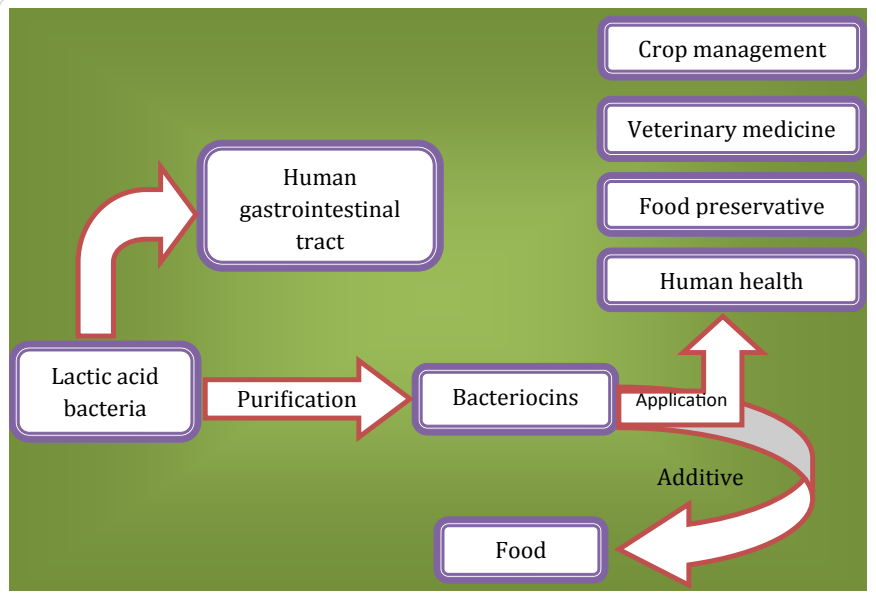

Figure 1: Over view of the applications of bacteriocin produced by LAB.

*Corresponding author: Nishant Toomula, Department of Biotechnology GITAM Institute of Technology, GITAM University, Visakhapatnam, India, E-mail: nishanththumula@gmail.com

Received November 07, 2011; Accepted December 12, 2011; Published December 15, 2011

Citation: Nishant T, Sathish Kumar D, Arun Kumar R, Hima Bindu K, Raviteja Y (2011) Bacteriocin Producing Probiotic Lactic acid Bacteria. J Microbial Biochem Technol 3: 121-124. doi:10.4172/1948-5948.1000062

Copyright: ( 2011 Nishant T, et al. This is an open-access article distributed under the terms of the Creative Commons Attribution License, which permits unrestricted use, distribution, and reproduction in any medium, provided the original author and source are credited 
Bacteriocins are proteinaceous toxins ribosomally synthesized single polypeptides produced by bacteria to inhibit the growth of similar or closely related bacterial strain(s).

Bacteriocins were first discovered by A. Gratia in 1925. He was involved in the process of searching for ways to kill bacteria, which also resulted in the development of antibiotics [11] and the discovery of bacteriophage [12], all within a span of a few years. He called his first discovery a colicine because it killed E. coli. Escherichia coli (E. coli) belong to a group of pathogenic bacteria called gram-negative enterobacteria that also includes Salmonella and Pseudomonas $[13,14]$. E. coli and Salmonella found in contaminated foods can cause diarrhea, and even death in severe cases $[15,16]$. Bacteriocins are categorized in several ways, including producing strain, common resistance mechanisms, and mechanism of killing. There are several large categories of bacteriocin which are only phenomenologically related (Table 1). These include the bacteriocins from gram positive bacteria- the colicins, microcins, bacteriocins from Archaea. Besides the production of bacteriocins, some LAB are able to synthesize other antimicrobial peptides that may also contribute to food preservation and safety [17-19].

\section{Classification of bacteriocins}

According to Klaen hammer [20], bacteriocins can be classified into four groups on the basis of to their molecular mass, thermo-stability, enzymatic sensitivity, presence of posttranslationally modified amino acids, and mode of action.

Class I bacteriocins: The class I bacteriocins are small peptide inhibitors and include nisin and other lantibiotics. They are further

\begin{tabular}{|l|l|}
\hline \multicolumn{1}{|c|}{ Substance } & \multicolumn{1}{c|}{ Producing Organism } \\
\hline Curvalicin & Lactobacillus curvatus \\
\hline Acidocin J1132 $\beta$ & Lactobacillus acidophilus \\
\hline Plantaricin S $\beta$ & Lactobacillus plantarum \\
\hline Bacteriocin J46 & Lactococcus lactis \\
\hline Lacticin 481 (Lactococcin DR) & Lactococcus lactis subsp (Streptococcus lactis) \\
\hline Lactocin-705 & Lactobacillus paracasei \\
\hline Nisin & Lactococcus lactis subsp (Streptococcus lactis) \\
\hline Plantaricin C19 & Lactobacillus plantarum \\
\hline Lactocin-S & Lactobacillus sakei \\
\hline Lactococcin MMFII & Lactococcus lactis subsp (Streptococcus lactis) \\
\hline Curvaticin FS47 & Lactobacillus curvatus \\
\hline Bavaricin & Lactobacillus sakei \\
\hline Curvacin-A & Lactobacillus curvatus \\
\hline Sakacin-A, Sakacin-P & Lactobacillus sakei \\
\hline Lactococcin-B & $\begin{array}{l}\text { Lactococcus lactis subsp (Streptococcus } \\
\text { cremoris) }\end{array}$ \\
\hline Lactobin-A (Amylovorin-L471) & Lactobacillus amylovorus \\
\hline Lactacin-F (lafA) & Lactobacillus johnsonii \\
\hline Plantaricin W a & Lactobacillus plantarum \\
\hline Plantaricin 1.25 $\beta$ & Lactobacillus plantarum \\
\hline Acidocin B (AcdB) & Lactobacillus acidophilus \\
\hline Reutericin & Lactobacillus reuteri \\
\hline
\end{tabular}

Table 1: Bacteriocins produced by different Lactobacillus species. divided into two subgroups on the basis of structure and charge of the compound: Group Ia, which consists of screw-shaped, amphipathic, small cationic peptides that produce voltage-dependent pores by unspecific interaction with the membrane of the target cell; and group Ib, which consists of anionic or neutral peptides having a globular shape.

Class II bacteriocins: This group comprises heat-stable peptides with molecular masses smaller than $10 \mathrm{kDa}$ and with no modified amino acids. Members of this class can be further sub-classified into four groups: Group IIa consists of anti-listerial peptides showing the consensus sequence YGNGV at their N-terminal sequence. Class IIa bacteriocins have a large potential for use in food preservation as well medical applications, due to their strong antilisterial activity, and broad range of activity. The class IIb bacteriocins (two-peptide bacteriocins) require two different peptides for activity. Other bacteriocins can be grouped together as Class IIc (circular bacteriocins). These have a wide range of effects on membrane permeability, cell wall formation and pheromone actions of target cells.

Class III bacteriocins: This group consists of peptidic antibiotics that are heat-labile proteins with a molecular mass larger than $30 \mathrm{kDa}$.

Class IV bacteriocins: This group consists of either glycoproteins $[21,22]$ or lipoproteins $[23,24]$ that require non-protein moieties for their activity.

\section{Probiotics}

Probiotics are live microorganisms thought to be healthy for the host organism. According to the currently adopted definition by WHO, probiotics are: "Live microorganisms which when administered in adequate amounts confer a health benefit on the host" $[25,26]$.

The term "probiotics" was first introduced in 1953 by Kollath [27]. Lactic acid bacteria were referred to as probiotics in scientific literature by Lilley and Stillwell (1965). However probiotic took on a different terminology when Sperti in 1971 used the term "probiotic" to describe tissue extracts that stimulated microbial growth. Parker in 1974 redefined it as organisms and substances that contribute to the intestinal microbial balance [28]. The most recent and accurate description of probiotics was undertaken by Fuller who redefined it as" a live microbial feed supplement beneficial to the host by improving the microbial balance within its body" [29]. Probiotics also appear to enhance the host response towards disease, and improve the quality of the rearing environment [30,31]Benefits of probiotic LAB.

Experiments into the benefits of probiotic therapies suggest a range of potentially beneficial medicinal uses for probiotics [32]. Recent research on the molecular biology and genomics of Lactobacillus has focused on the interaction with the immune system [33,34], anticancer potential, and potential as a biotherapeutic agent in cases of antibiotic-associated diarrhoea, travellers' diarrhoea, pediatric diarrhoea, inflammatory bowel disease [35] and irritable bowel syndrome. Lactobacilli provide the enzyme $\beta$-galactosidase which hydrolyzes lactose into lactic acid; it helps in maintaining lactose intolerance (Figure 2).

Most human trials have found that the LAB strains tested may exert anti-carcinogenic effects by decreasing the activity of an enzyme called $\beta$-glucuronidase which can generate carcinogens (Heterocyclic amines) in the digestive system [36,37]. Lactobacilli deconjugate the bile salts in the intestine to form bile acids and thereby inhibit micelle 


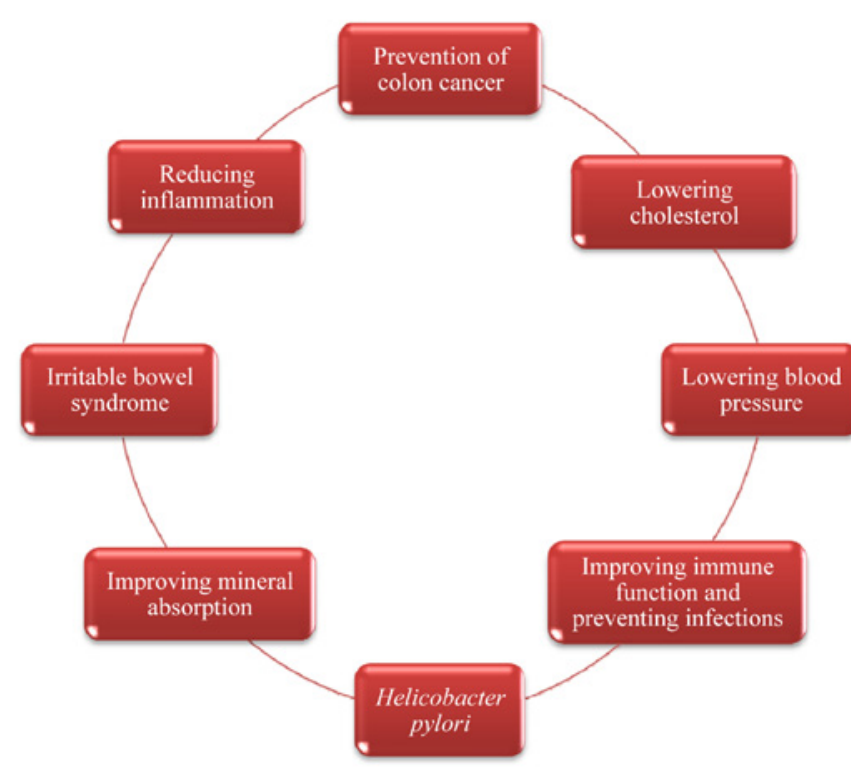

Figure 2: Potential benefits of Probiotics.

formation. This leads to decreased absorption of cholesterol [38]. Several small clinical trials have indicated that consumption of milk fermented with various strains of LAB may result in modest reductions in blood pressure. It is thought that this is due to the ACE inhibitor-like peptides produced during fermentation.

Lactic acid bacteria have several beneficial effects on immune function such as protecting against pathogens by competitive inhibition and also improve immune function by increasing IgA producing plasma cells [39], increasing or improving phagocytosis as well as increasing the proportion of $\mathrm{T}$ lymphocytes and natural killer cells $[40,41]$. Probiotics are also known to reduce dental carries in children as well as aid in the treatment of Helicobacter pylori infection $[42,43]$.

\section{Mechanism by which probiotics influence human health}

Studies have shown that probiotics can down regulate inflammation and responses to allergens, and interfere with pathogen infections either directly or through enhancing gut barrier function [44]. Probiotics can also serve a role for stabilizing intestinal microflora [45]. Many of the mechanisms are similar to the roles that our normal colonizing microfloras play. Probiotics can down regulate:

$>$ Inflammation $[46,47]$

$>$ Responses to allergens

$>$ Pathogen infections( interference); and

$>$ Alteration in the gut

\section{Conclusion}

The potential application of bacteriocins as consumer friendly biopreservatives either in the form of protective cultures are as additives is significant. LABS are typically involved in a large number of spontaneous food fermentations. Food fermentations have a great economic value and it has been accepted that these products contribute in improving human health. LABS have contributed in the increased volume of fermented foods worldwide especially in foods containing probiotics or health promoting bacteria. Bacteriocins produced by $\mathrm{LAB}$ are the subject of intense research because of their antibacterial activity against food borne bacteria.

\section{References}

1. Axelsson L, Holck A (1995) The genes involved in production of and immunity to sakacin A, a bacteriocin from Lactobacillus sakei Lb706. J Bacteriol 177 2125-2137.

2. Khan MA, Semwal AD, Sharma GK, Mahesh C, Nataraj S, et al. (2011) Development and Evaluation of Long Shelf-Life Ambient Stable Chapaties Without The Use of Chemical Preservatives. J Food Process Technol 2: 107.

3. Shukla P, Vishwakarma P (2011) Biochemical and Microbial Examination of Sulphi and Cheend: Two Alcoholic Beverages from Central India. J Nutr Food Sci 1: 105 .

4. de Lima CJB, Coelho LF, da Silva GP, Alvarez G, Contiero J (2010) L(+) Lactic Acid Production by New Lactobacillus Rhamnosus B 103. J Microbial Biochem Technol 2: 064-069.

5. Benerji DSN, Ayyanna C, Rajini K, Rao BS, Banerjee DRN, et al. (2010) Studies on Physico-Chemical and Nutritional Parameters for the Production of Ethanol from Mahua Flower (Madhuca indica) Using Saccharomyces Cerevisiae 3090 Through Submerged Fermentation (smf). J Microbial Biochem Techno 2: 046-050.

6. Dajanta K, Apichartsrangkoon A, Chukeatirote E (2011) Antioxidant properties and total phenolics of thua nao (a Thai fermented soybean) as affected by Bacillus-fermentation. J Microbial Biochem Technol 3: 056-059.

7. De Vugst L, Vandamme EJ (1994) Bacteriocins of lactic acid bacteria, microbiol Genet Appl. London: Blackie Acad and professional. 75: 140174-1401749.

8. Elbanna K, Hassan G, Khider M, Mandour R (2010) Safe Biodegradation of Textile Azo Dyes by Newly Isolated Lactic Acid Bacteria and Detection of Plasmids Associated With Degradation. J Bioremed Biodegrad 1: 110.

9. Pathak H, Bhatnagar K (2011) Alcaligenes-The 4T Engine Oil Degrader. J Bioremed Biodegrad 2: 124.

10. Felix S, Pradeepa P (2011) Seaweed (Ulva reticulata) Based Fermented Marine Silage Feed Preparation under Controlled Conditions for Penaeus monodon Larval Development. J Marine Sci Res Development 1: 103.

11. Narasimhulu K, Rao PS, Vinod AV (2010) Isolation and Identifi cation of Bacterial Strains and Study of their Resistance to Heavy Metals and Antibiotics. J Microbial Biochem Technol 2: 074-076.

12. Bell E, Spencer J, Mattey M (2011) Better Luck Next Time: The Tesurrection of Bacteriophage Therapy. J Bioanal Biomed S6: 001.

13. Wasi S, Tabrez S, Ahmad M (2010) Isolation and Characterization of a Pseudomonas fluorescens Strain Tolerant to Major Indian Water Pollutants. J Bioremed Biodegrad 1: 101.

14. St-Onge R, Goyer C, Filion M (2010) Pseudomonas Spp. can Inhibit Streptomyces scabies Growth and Repress the Expression of Genes Involved in Pathogenesis. J Bacteriol Parasitol 1: 101.

15. Kaur P, Chakraborti A (2010) Proteome Analysis of a Food Borne Pathogen Enteroaggregative Escherichia coli under Acid Stress. J Proteomics Bioinform 3: 010-019.

16. Wang A, Molina G, Prima V, Wang KKW (2011) Anti-LPS Test Strip for the Detection of Food Contaminated with Salmonella and E. coli. J Microbial Biochem Technol 3: 026-029.

17. Coates A, Trounce MB (2011) FDA Food Safety Modernization Act: Is it Enough? J Bioterr Biodef 2: 109.

18. Xu Y, Bianchini A, Hanna MA (2011) Evaluation of Mold and Mycotoxin Contaminations in Hybrid Hazelnuts Grown in Nebraska. J Food Process Technol 2: 119.

19. Kristiansen M, Merrifield DL, Vecino JLG, Myklebust R, Ringø E (2011) Evaluation of Prebiotic and Probiotic Effects on the Intestinal Gut Microbiota and Histology of Atlantic salmon (Salmo salar L.) J Aquac Res Development S1: 009. 
Citation: Nishant T, Sathish Kumar D, Arun Kumar R, Hima Bindu K, Raviteja Y (2011) Bacteriocin Producing Probiotic Lactic acid Bacteria. J Microbial Biochem Technol 3: 121-124. doi:10.4172/1948-5948.1000062

20. Klaenhammer TR (1993) Genetics of bacteriocins produced by lactic acid bacteria. FEMS Microbiol Rev 12: 39-85

21. Tran TT, Nguyen TMP, Nguyen BN, Phan VC (2008) Changes of Serum Glycoproteins in Lung Cancer Patients. J Proteomics Bioinform 1: 011-016.

22. Upreti GC, Hinsdill RD (1975) Production and mode of actionof lactocin 27: bacteriocin from a homofermentative Lactobacillus. Antimicrob Agents Chemother 7: 139-145.

23. Zhao Y, Guo Z, Lin X, Zhou L, Okoro EU, et al. (2010) Apolipoprotein E-Defi cient Lipoproteins Induce Foam Cell Formation by Activation of PERK-EIF-2a Signaling Cascade. J Bioanal Biomed 2: 113-120.

24. Kozak W, Bardowski J, Dobrzanski WT (1977) Lacstrepcin-a bacteriocin produced by Streptococcus lactis. Bull Acad Pol Sci 25: 217-221.

25. Gioacchini G, Lombardo F, Merrifield DL, Silvi S, Cresci A, et al. (2011) Effects of Probiotics on Zebrafish Reproduction. J Aquac Res Development S1: 002.

26. Liu Y, Wang Y, Gang J (2011) Challenges of microarray applications for microbial detection and gene expression profiling in food. J Microbial Biochem Technol S2: 001.

27. Hamilton-Miller JMT (2004) Probiotics and prebiotics in the elderly. Postgrad Med J 80: 447-451.

28. Aly S, Cheik OAT, Bassole IHN, Alfred TS (2006) Bacteriocins and lactic acid bacteria - a minireview. African Journal of Biotechnology 5: 678-683.

29. Welker TL, Lim C (2011) Use of Probiotics in Diets of Tilapia. J Aquac Res Development S1: 014.

30. Murillo I, Villamil L (2011) Bacillus cereus and Bacillus subtilis used as probiotics in rotifer (Brachionus plicatilis) cultures. J Aquac Res Development S1: 007.

31. Gatesoupe FJ (1999) The use of probiotics in aquaculture. Aquaculture 180: $147-165$.

32. Bruno MEC, Montville TJ (1993) Common mechanistic action of bacteriocins from lactic acid bacteria. Appl Environ Microbiol 59: 3003-3010.

33. Durlu-özkaya F, Özkaya MT (2011) Oleuropein using as an Additive for Feed and Products used for Humans. J Food Process Technol 2: 113.

34. Castellanos MI, Seijas OR, González D, Ronquillo M, del Rosario Abreu M, et al. (2011) Immune Alterations in Liver Cirrhosis: Its Relationship with Etiology, Child Pugh Stage and Malnutrition. J Nutrition Disorder Ther 1: 101
35. Karatepe O, Kokdas S, Kamali S, Aydın T, Kemik A, et al. (2010) The Comparison between Laparoscopic vs. Open Surgery for Trinitrobenzene Sulfonic Acid-Induced Rat Colitis. J Cytol Histol 1: 109.

36. Zaidi R, Rawat PR (2011) Identification of Heterocyclic Amines in Indian Home Cooked and Commercially Available Meat Foods. J Nutr Food Sci 1: 107.

37. Kizil M, Oz F, Besler HT (2011) A Review on the Formation of Carcinogenic Mutagenic Heterocyclic Aromatic Amines. J Food Process Technol 2: 120.

38. Nagendra Prasad MN, Sanjay KR, Shravya Khatokar M, Vismaya MN Nanjunda Swamy S (2011) Health Benefits of Rice Bran - A Review. J Nutr Food Sci 1: 108.

39. Castellanos MI, Seijas OR, González D, Ronquillo M, del Rosario Abreu M, e al. (2011) Immune Alterations in Liver Cirrhosis: Its Relationship with Etiology, Child Pugh Stage and Malnutrition. J Nutrition Disorder Ther 1: 101.

40. Naga Deepthi C, Phani Santosh, Prithvi Raj (2011) Evaluation of the Various uses of Microorganisms with Emphasis on Probiotics. J Microbial Biochem Technol R1: 004

41. Pivaral CEC (2011) Is Natural Latex an Important Cause of Allergy? J Aller Ther 2: $102 \mathrm{e}$.

42. Watanabe K, Hashizume T, Kurita-Ochiai T, Akimoto Y, Yamamoto M (2010) Nasal Administration of Glucosyltransferase-I of Streptococcus sobrinus without Adjuvant Induces Protective Immunity. J Vaccines Vaccin 1: 109.

43. Narwal A (2011) Probiotics in Dentistry - A Review. J Nutr Food Sci 1: 114.

44. Yang HL, Sun YZ, Ma RL, Li JS, Huang KP (2011) Probiotic Psychrobacter sp. improved the autochthonous microbial diversity along the gastrointestina tract of grouper Epinephelus coioides. J Aquac Res Development S1: 001.

45. Yadav H, Jain S, Marotta F (2011) Probiotics Mediated Modulation of GutFlora Might Be a Biotherapeutical Approach for Obesity and Type 2 Diabetes. Metabolomics 1: 107e.

46. Singh RK, Sudhakar A, Lokeshwar BL (2011) From Normal Cells to Malignancy: Distinct Role of Pro-inflammatory Factors and Cellular Redox Mechanisms. J Cancer Sci Ther 3: 070-075.

47. Liu DM, Cade D, Klass D, Loh C, McWilliams JP et al. (2011) Interventional Oncology - Avoiding Common Pitfalls to Reduce Toxicity in Hepatic Radioembolization. J Nucl Med Radiat Ther 2: 106. 